\title{
Profiling of suppressive immune subsets in metastasis negative and positive sentinel lymph nodes from patients with HER2- breast cancer
}

\author{
Rieneke van de Ven ${ }^{1 *}$, Kim van Pul ${ }^{2}$, Shaghayegh Aliabadi ${ }^{3}$, M Petrousjka van den Tol ${ }^{2}$, Daniel Haley ${ }^{3}$, \\ Raina Tamakawa ${ }^{3}$, Ronald J Vuylsteke ${ }^{4}$, Hein B Stockmann ${ }^{4}$, Julie L Cramer ${ }^{3}$, Walter J Urba ${ }^{3}$, Bernard A Fox ${ }^{3}$, \\ Tanja D de Gruijl ${ }^{1}$
}

From Society for Immunotherapy of Cancer 29th Annual Meeting

National Harbor, MD, USA. 6-9 November 2014

\section{Background}

Since it is the site of initial immune activation and priming of antigen-specific $\mathrm{T}$ cells, as well as the first location to which tumor cells metastasize, our research focuses on understanding the immune status and tumor-induced suppression within breast cancer $(\mathrm{BrCa})$ draining sentinel lymph nodes (SLN).

\section{Methods}

Suppressive immune subsets were profiled by multi-color flow cytometry in two different BrCa SLN cohorts. In the first cohort, collected at the Providence Cancer Center (08/11-07/13), we looked at frequencies of HLA-DR$\mathrm{CD} 14+$ myeloid cells and their expression of co-stimulatory and inhibitory receptors. Four metastasis+ SLN and 11 metastasis- SLN were assessed in this cohort. SLN in the second cohort were collected at the VUmc in Amsterdam and Kennemer Gasthuis in Haarlem (10/13-06/14) and contained 2 metastasis+ and 7 metastasis- SLN. In this cohort the frequencies of HLA-DR- CD14+ cells as well as CD25_hi FoxP3+ T regulatory cells (Treg) were analyzed. Since all tumors corresponding to the metastasis + SLN turned out to be HER2 negative, only metastasisSLN from HER2- tumors were included. Apart from 2 tumors in the Providence cohort, all tumors did express progesterone and/or estrogen receptors.

'VU University Medical Center / Department of Medical Oncology,

Amsterdam, Netherlands

Full list of author information is available at the end of the article

\section{Results}

Elevated frequencies of HLA-DR- CD14+ immature myeloid cells could be detected in the metastasis+ SLN in both cohorts. This difference was statistically significant for the Providence cohort ( $\mathrm{p}<0.0001)$ (3.8 fold increase). No differences were observed for expression levels of the co-stimulatory molecules CD80 and CD86 or the inhibitory molecules PD-L1 and B7H4 on HLADR- CD14+ cells between positive or negative SLN and expression was low for all these markers. Due to the small number of metastasis+ SLN in the Dutch cohort statistics could not yet be performed, but a 2.3 fold increase in HLA-DR-CD14+ cells was seen. In this cohort, frequencies of Treg were found to be 4 -fold higher in the metastasis+ SLN compared to metastasisSLN $(0.31 \pm 0.22$ vs. $1.22 \pm 0.24$ Treg of CD4 T cells). Moreover, a significant correlation was observed between the frequencies of HLA-DR- CD14+ immature myeloid cells and the frequencies of Treg in these $\mathrm{BrCa}$ SLN $(r=0.718, p<0.01)$.

\section{Conclusion}

Our data suggest that tumor-derived factors negatively influence both the myeloid and the lymphoid compartments within SLN draining HER2 negative breast cancers.

\section{Consent}

Written informed consent was obtained from the patient for publication of this abstract and any accompanying images. A copy of the written consent is available for review by the Editor of this journal. 


\section{Acknowledgements}

This work was supported by the Dutch Cancer Society, A Sister's Hope foundation, Providence Medical Center Foundation, Robert W. Franz, Wes and Nancy Lematta, Lyn and Jack Loacker and the Chiles Foundation.

\section{Authors' details}

'VU University Medical Center / Department of Medical Oncology,

Amsterdam, Netherlands. ${ }^{2}$ VU University Medical Center / Department of Surgical Oncology, Amsterdam, Netherlands. ${ }^{3}$ Robert W. Franz Cancer

Research Center at the Earle A. Chiles Research Institute, Providence Cancer Center, Portland, OR, USA. ${ }^{4}$ Kennemer Gasthuis / Department of Surgery,

Haarlem, Netherlands.

Published: 6 November 2014

doi:10.1186/2051-1426-2-S3-P237

Cite this article as: van de Ven et al:: Profiling of suppressive immune subsets in metastasis negative and positive sentinel lymph nodes from patients with HER2- breast cancer. Journal for ImmunoTherapy of Cancer 2014 2(Suppl 3):P237.

\section{Submit your next manuscript to BioMed Central} and take full advantage of:

- Convenient online submission

- Thorough peer review

- No space constraints or color figure charges

- Immediate publication on acceptance

- Inclusion in PubMed, CAS, Scopus and Google Scholar

- Research which is freely available for redistribution

Submit your manuscript at www.biomedcentral.com/submit 